\title{
СУИЦИДААЬНОЕ ПОВЕДЕНИЕ В СТРУКТУРЕ ЗАЩИТНЫХ СПОСОБОВ ПРЕОДОАЕНИЯ МИГРАЦИОННОГО И УЧЕБНОГО СТРЕССА ИНОСТРАННЫМИ СТУДЕНТАМИ
}

\author{
B.В. Руженкова \\ ФГАОУ ВО «Белгородский государственный национальный исследовательский университет», \\ г. Белгород, Россия
}

\section{Контактная информация:}

Руженкова Виктория Викторовна - кандидат медицинских наук (SPIN-код: 8424-7632; ORCiD: 00000002-1740-4904; Researcher ID: E-9468-2018; SCOPUS Author ID: 56362612200). Место работы и должность: доцент кафедры психиатрии, наркологии и клинической психологии Медицинского института ФГАОУ ВО «Белгородский государственный национальный исследовательский университет». Адрес: г. Белгород, ул. Победы, 82. Темефон: (980) 323-65-06, эмектронный адрес: ruzhenkova@bsu.edu.ru

Студенты-медики, приезжающие на обучение в другую страну, испытывают определённые трудности в адаптации к нормам и ценностям принимающей культуры, а также значительный учебный стресс, сопровождающийся тревогой и депрессией. Целью исследования была разработка рекомендаций по преодолению учебного стресса студентами-медиками, приехавшими из других стран, на основе изучения его распространенности, феноменологических проявлений и обусловливающих факторов. Материал и методы. Медикосоциологическим и психометрическим методами обследована сплошная выборка, состоящая из 166 студентов 1-3 курсов, прибывших из стран Ближнего Востока и Индии, не владеющих русским языком и обучающихся на языке посреднике (английском) в медицинском институте. Для обработки базы данных использовались непараметрические статистические методы. Результаты. Установлено, что студенты-иностранцы в первые месяцы адаптации переживают выраженное стрессовое напряжение, в 44\% случаев сопровождающееся внутренними формами суицидального поведения. При этом, степень выраженности суицидальных мыслей по 10балльной шкале составила 5-9 баллов у 29,7\% студентов первого, 27,3\% - второго и 14\% - третьего курса. Основными проявлениями стресса у студентов являются наплывы посторонних мыслей, подавленность, раздражительность, тревога, а также вегетативные симптомы (учащенное сердцебиение, затруднённое дыхание, головные боли, проблемы с желудочно-кишечным трактом), которые входят в структуру депрессивного и тревожно-депрессивного синдромов, являющихся психопатологической основой для возникновения суицидального поведения. Суицидальные мысли чаще встречались среди студентов, испытывающих средние и серьёзные трудности во время учёбы $(\mathrm{U}=630,0 ; \mathrm{Z}=-2,16 ; \mathrm{p}=0,031)$. Вероятность развития депрессии у студентов 1 курса в 2,6 раза выше (OR=2,6; 95\% CI=1,2-5,7), чем у второго, и выявляется у $31 \%$ и - 17,8\% студентов соответственно $\left(\chi^{2}=6,3 ; \mathrm{df}=1 ; \mathrm{p}=0,013\right)$. Тревога различной степени выраженности наблюдалась у $50 \%$ студентов первого, и 35\% второго и третьего курсов. Для преодоления стресса студенты употребляют настои трав и нерецептурные седативные препараты. При этом молодые люди, у которых возникали мысли о нежелании жить в период адаптации, чаще, чем студенты без суицидальных мыслей, принимали настои трав $(\mathrm{p}=0,002)$ и нерецептурные седативные препараты $(\mathrm{p}=0,016)$ для преодоления стрессового напряжения. С 1 по 3 курс отмечается рост числа иностранных студентов, употребляющих алкоголь и прибегающих к табакокурению. Заключение. Полученные данные указывают на необходимость обучения студентов конструктивным приёмам преодоления стресса, грамотному планированию времени, методам оптимальной самостоятельной работы с учебной литературой, что будет способствовать преодолению миграционного и учебного стресса, улучшит адаптационные возможности.

Ключевые слова: учебный стресс, миграционный стресс, студенты медики, суицидальное поведение, аутоагрессивное поведение

Студенты, выезжающие на обучение в другие страны и временно в них пребывающие, испытывают ряд эмоциональных трудностей в условиях начальной адаптации к нормам и ценностям принимающей культуры [1]. В условиях меняющихся бытовых условий и новых требований к учебной адаптации [2], наиболее стрессогенными для иностранных студентов оказываются большой объём учебного материала [3], климат и языковый барьер [4]. Немаловажное значение имеют также социальные проблемы, различные стили обучения, академические требования, расизм, тоска по родине, отсутствие уверенности в себе и 
финансовые сложности [5]. При этом степень интеграции иностранных студентов в новой культурной среде зависит от национальных, религиозных и климато-географических различий, а также индивидуальных особенностей [6].

Проблемы адаптации в иноязычной среде особенно касаются студентов медиков, так как учебная нагрузка у них в среднем в 2 раза выше, чем у учащихся других ВУЗов [7], а деятельность студента-медика в целом относится к числу напряжённых в эмоциональном плане видов труда, что отражается на уровне их психического и соматического здоровья $[8,9]$.

У студентов медиков регистрируется высокий уровень учебного стресса, приводящий к возникновению суицидального поведения (суицидальных мыслей и попыток) - от 32,5\% [10] до 83\% [11]. Более того [12], у поступающих в медицинские институты изначально наблюдаются высокая частота стресса, тревоги и депрессии. В целом, студентов с суицидальными наклонностями отличают мнительность, тревожность, исполнительность, аккуратность, высокая выраженность неуверенности в себе, сочетающиеся с эмоциональным «тоскливым» напряжением, требующим разрядки [13]. Учитывая тот факт, что у лиц молодого возраста жизненный опыт и знания обладают минимальным защитным потенциалом и ограничивают возможность выработки стратегий преодоления [14], студенты с затруднениями в адаптации нуждаются в психологической поддержке. Большая подверженность развитию тревоги и депрессии, эмоционального и когнитивного выгорания, снижению уровня ментального здоровья обычно характерна для студенток $[15,16,17]$. Кроме того, в период с 1 по 6-й год обучения сокращается на 40,4\% доля учащихся с удовлетворительной адаптацией [18]. Эмоциональное напряжение и стресс обусловливают употребление студентами психоактивных веществ - наркотиков, алкоголя, курение табака $[19,20]$.

Большое значение для профилактики учебного стресса играют имеющие в учебном заведении системы поддержки студентов [21]. Так, студенты-медики обращают внимание на то, что их учат распознавать и облегчать страдания пациентов, и считают это «неотъемлемой функцией врача», но образование не готовит их к реагированию на их личные страдания [22]. Часто выбираемые студентами для совладания со стрессом пассивные копинг-стратегии увеличивают риск несуицидального аутоагрессивного поведения и самоповреждений [23]. В то же время актуализация адаптационного потенциала и копинг-ресурсов каждого студента может способствовать повышению их адаптации и минимизации эмоционального выгорания [24].

По мнению самих студентов наиболее полезными являются социальная поддержка со стороны сверстников и преподавателей, консультационные услуги, дискуссии в малых группах, а также обмен опытом, различные внеклассные и внеучебные мероприятия, дающие возможность «выпустить пар», снять эмоциональное напряжение, расслабиться $[25,26]$.

Это диктует необходимость разработки рекомендаций по преодолению учебного стресса студентами-медиками, приехавшими из других стран, на основе изучения его распространенности, феноменологических проявлений и обусловливающих факторов, что и явилось целью настоящего исследования.

Материал и методы.

Обследована сплошная выборка, состоящая из 166 студентов 1-3 курсов, прибывших из стран Ближнего Востока и Индии, не владеющих русским языком и обучающихся на языке посреднике (английском) в медицинском институте. Возраст студентов на период обследования от 17 до 29 лет (средний $-20,8 \pm 1,8$ ), 137 человек мужского и 29 женского пола.

Распределение обследованных студентов по курсам и полу представлено в таблице 1 .

Основные методы обследования:

1.Медико-соииологический (анонимное анкетирование при помощи авторской анкеты, содержащей социально-демографическую информацию, вопросы, касающиеся адаптации к новым условиям проживания, отношения к выбранной специальности, условий обучения и проживания).

Таблица 1

Распределение студентов по курсам и полу

\begin{tabular}{l|c|c|c|c|c|c|c|c}
\hline \multirow{2}{*}{ Пол } & \multicolumn{2}{|c|}{1 курс } & \multicolumn{2}{c|}{2 курс } & \multicolumn{2}{c|}{3 курс } & \multicolumn{2}{c}{ Всего } \\
\cline { 2 - 10 } & $\mathrm{n}$ & $\%$ & $\mathrm{n}$ & $\%$ & $\mathrm{n}$ & $\%$ & $\mathrm{n}$ & $\%$ \\
\hline Женский & 16 & 19,0 & 6 & 13,3 & 7 & 18,9 & 29 & 17,5 \\
\hline Мужской & 68 & 81,0 & 39 & 86,7 & 30 & 81,1 & 137 & 82,5 \\
\hline Итого: & 84 & 100,0 & 45 & 100,0 & 37 & 100,0 & 166 & 100,0 \\
\hline
\end{tabular}




\section{2. Психометрический:}

- тест на учебный стресс Ю.В. Щербатых [27]. Тест представляет собою набор шкал самооценки (от 0 до 10 баллов) субъективного восприятия степени воздействия группы учебных стрессовых факторов, выраженности симптомов учебного стресса, способов преодоления его преодоления и вариантов психосоматического реагирования перед экзаменами;

- опросник «GAD-7» [28];

- опросник DASS-21 - The Depression Anxiety Stress Scale [29] - для верификации уровня депрессии, тревоги и стресса.

3. Статистический. Применялись методы описательной непараметрической статистики, медиана, интерквартильный размах. При сравнении двух групп по бинарному признаку применялся критерий $\chi^{2}$ с поправкой Йетса на непрерывность; при сравнении двух независимых групп использовался U-тест Манна-Уитни; кроме того, проводился корреляционный (коэффициент ранговой корреляции Спирмена) и факторный анализ (методом главных компонент с varimax вращением фактора).

Результаты и обсуждение.

Объективизация точки зрения студентов на степень сложности адаптации в первые месяцы после приезда на учёбу в Россию (табл. 2) показала, что с течением времени и по мере привыкания к новому месту временного проживания, климатогеографическим и социальным особенностям территории, субъективное восприятия перенесённой фрустрации снижается: снижение у второго ( $U=1132,5 ; \mathrm{p}=0,017)$ и третьего курса ( $\mathrm{U}=906,0 ; \mathrm{p}=0,0002)$ по сравнению с первым.

Между вторым и третьим курсами различия статистически не значимы ( $U=603,0 ; \mathrm{p}=0,196)$. Этим объясняется динамикой медианного значения выраженности трудности адаптации от 50 баллов с точки зрения первокурсников, до $30-$ по оценке студентов 3 курса.
Медианное значение этого показателя (по 100 балльной шкале) составило 50 баллов, что свидетельствует о значительных трудностях в адаптации. При этом 31 (36,9\%) первокурсников оценили тяжесть адаптации в 50-70 баллов, a $17(20,2 \%)$ - в 80-100 баллов. Другими словами, более половины студентов $(57,1 \%)$ первого курса испытывают серьёзные затруднения в адаптации в первые месяцы обучения в иноязычной стране. Гендерные различия не выявлены $(\mathrm{U}=489,0 ; \mathrm{p}=0,655)$.

Таблийа 2

Степень трудности адаптации в первые месяцы

\begin{tabular}{c|c|c|c|c|c}
\hline \multicolumn{2}{c|}{$\begin{array}{c}\text { курс } \\
(\mathrm{n}=84)\end{array}$} & \multicolumn{2}{c|}{$\begin{array}{c}2 \text { курс } \\
(\mathrm{n}=45)\end{array}$} & \multicolumn{2}{c}{$\begin{array}{c}3 \text { курс } \\
(\mathrm{n}=37)\end{array}$} \\
\hline $\mathrm{Me}$ & $\mathrm{Q}_{25-75}$ & $\mathrm{Me}$ & $\mathrm{Q}_{25-75}$ & $\mathrm{Me}$ & $\mathrm{Q}_{25-75}$ \\
\hline 50,0 & $30-70$ & 40,0 & $20-50$ & 30,0 & $20-40$ \\
\hline
\end{tabular}

Среди факторов, обусловливающих наибольшие трудности для адаптации (табл. 3) был языковый барьер - для 75,6-75,7\% студентов 2 и 3 курса и 64,3\% - первого (различия статистически не значимы). На втором месте непривычная пища, иные, отличные от привычных, климатические условия. Отсутствие информации на английском и незнакомая территория города существенного значения не имели, так как за каждой группой иностранных студентов был закреплён куратор из числа преподавателей, который оказывал им существенную помощь в решении бытовых вопросов.

Тем не менее, для 19,0\% первокурсников $\left(\chi^{2}=5,854 ; \mathrm{df}=1 ; \mathrm{p}=0,016\right)$ важную роль играло субъективное восприятие негативного отношения окружающих. Это было связано с тем, что одним из основных способов преодоления стресса у этих студентов были пропуски занятий и необходимость последующей их отработки для получения зачёта. Последнее и интерпретировалось как предвзятое отношение.

Таблий 3

Факторы, создающие наибольшие трудности для адаптации

\begin{tabular}{l|c|c|c|c|c|c}
\hline \multirow{2}{*}{ Фактор } & \multicolumn{2}{c|}{1 курс (n=84) } & \multicolumn{2}{c|}{2 курс (n=45) } & \multicolumn{2}{c}{3 курс (n=37) } \\
\cline { 2 - 9 } & $\mathrm{n}$ & $\%$ & $\mathrm{n}$ & $\%$ & $\mathrm{n}$ & $\%$ \\
\hline Языковой барьер & 54 & 64,3 & 34 & 75,6 & 28 & 75,7 \\
\hline Непривычная еда & 27 & 32,1 & 12 & 26,6 & 11 & 29,7 \\
\hline Перемена климата & 21 & 25,0 & 11 & 24,4 & 7 & 18,9 \\
\hline Отсутствие информации на английском & 11 & 13,1 & 10 & 22,2 & 5 & 13,5 \\
\hline Незнакомая территория города & 7 & 8,3 & 4 & 8,9 & 1 & 2,7 \\
\hline Негативное отношение окружающих & 16 & 19,0 & 1 & 2,2 & 2 & 5,4 \\
\hline
\end{tabular}

Примечание: достоверных различий между группами не выявлено. 
Миграционный и учебный стресс в первые месяцы пребывания на территории другой страны обусловливал возникновение эмоциональной подавленности и суицидальных мыслей (рис. 1). Характерно, что у первокурсников в первые месяцы обучения суицидальные мысли возникали у 37 (44\%) человек. В то же время по ретроспективной оценке студентами 2 и 3 курса - эта цифра была статистически значимо $\left(\chi^{2}=10,51 ; \mathrm{df}=1 ; \mathrm{p}=0,002\right)$ ниже и составила соответственно $11(24,4 \%)$ и $7(18,9 \%)$. Это обусловлено успешным приспособлением к новым условиям жизни и снижением актуальности прежних проблем в адаптации. Вероятность такой ретроспективной оценки довольно высокая $(\mathrm{OR}=3,9 ; 95 \% \mathrm{CI}=1,6-9,5)$.

Полученные данные сопоставимы с ранее проведёнными исследованиями, и занимают промежуточное положение. Так, Д.Ф. Хритинин с соавт. [13] указывает, что $40,7 \%$ студентов-медиков имели суицидальные мысли в настоящем или в прошлом, в то время как западные исследователи [11] приводят несколько иные цифры, говоря, что 66\% студентов признавали, что при стрессе у них есть мысли о самоубийстве, $17 \%$ - заявляли, что у них стресс редко сопровождается суицидальными мыслями, и лишь $17 \%$ студентов отрицали наличие мыслей о нежелании жить. В работе Л.Н. Васильевой и С.С. Щепетковой [30] приводятся данные о более высоком риске суицидального поведения среди первокурсников по сравнению со студентами старших курсов, косвенно подтверждающие данные, полученные в нашем исследовании.

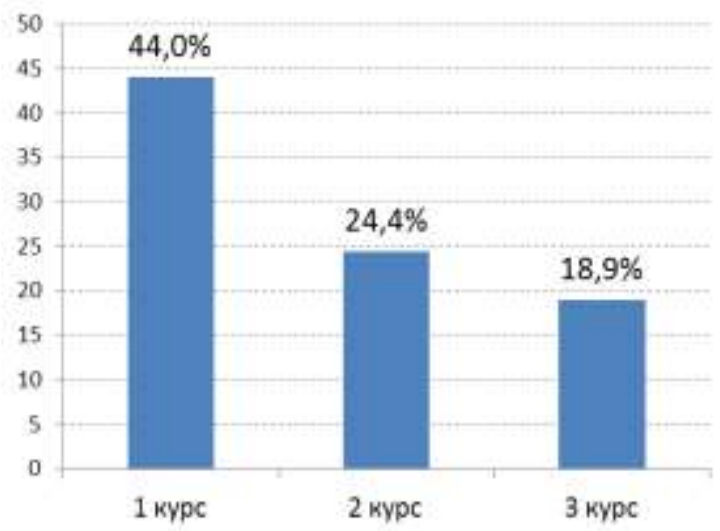

Примечание: 2 и 3 курсы - при ретроспективной оценке.

Puc. 1. Доля студентов 1-3 курсов, которые отмечали суицидальные мысли в первые месяцы адаптации.
Распределение иностранных студентов, имевших суицидальные мысли, по полу представлено в таблице 4.

Таблицุа 4

Гендерное распределение

\begin{tabular}{c|c|c|c|c|c|c}
\hline \multirow{2}{*}{ Пол } & \multicolumn{2}{|c|}{$\begin{array}{c}1 \text { курс } \\
(\mathrm{n}=37)\end{array}$} & \multicolumn{2}{c|}{$\begin{array}{c}2 \text { курс } \\
(\mathrm{n}=11)\end{array}$} & \multicolumn{2}{c}{$\begin{array}{c}3 \text { курс } \\
(\mathrm{n}=7)\end{array}$} \\
\cline { 2 - 7 } & $\mathrm{n}$ & $\%$ & $\mathrm{n}$ & $\%$ & $\mathrm{n}$ & $\%$ \\
\hline Женский & 8 & 21,6 & 1 & 9,1 & 1 & 14,3 \\
\hline Мужской & 29 & 78,4 & 10 & 90,9 & 6 & 85,7 \\
\hline
\end{tabular}

Необходимо отметить, что суицидальные мысли одинаково часто встречались среди первокурсников обоих полов, и были характерны для 8 (50,0\%) первокурсниц и 29 (42,6\%) первокурсников. При ретроспективной оценке мысли, связанные с нежеланием жить, отметила 1 студентка второго и 1 - третьего курса, 10 $(25,6 \%)$ второкурсников и $6(20,0 \%)$ третьекурсников.

Отсутствие статистически достоверных гендерных различий в частоте суицидальных мыслей свидетельствует о синергизме и взаимном усилении учебного и миграционного стресса, а также говорит о бо̀льшей гибкости психики лиц женского пола, готовых меняться, адаптируясь к принимающей культуре, её ценностям и порядкам, и некоторой ригидности лиц мужского пола, пытающихся сохранить привычный образ жизни в новых условиях.

Степень выраженности суицидальных мыслей по 10 балльной шкале (табл. 5) составила: 5-9 баллов почти у трети первокурсников и второкурсников с внутренними формами суицидального поведения $(29,7 \%$ и $27,3 \%$ соответственно) и у $14 \%$ третьекурсников. Статистически достоверных различий между курсами выявлено не было.

Таблица 5

Степень выраженности суицидальных мыслей по 10 балльной шкале

\begin{tabular}{l|c|c|c|c|c|c}
\hline $\begin{array}{c}\text { Степень } \\
\begin{array}{c}\text { выраженности } \\
\text { суицидальных } \\
\text { мыслей }\end{array}\end{array}$ & \multicolumn{2}{|c|}{$\begin{array}{c}1 \text { курс } \\
(\mathrm{n}=37)\end{array}$} & \multicolumn{2}{c|}{$\begin{array}{c}2 \text { курс } \\
(\mathrm{n}=11)\end{array}$} & \multicolumn{2}{c}{$\begin{array}{c}3 \text { курс } \\
(\mathrm{n}=7)\end{array}$} \\
\cline { 2 - 8 } & $\mathrm{n}$ & $\%$ & $\mathrm{n}$ & $\%$ & $\mathrm{n}$ & $\%$ \\
\hline $1-4$ балла & 26 & 70,3 & 8 & 72,7 & 6 & 85,7 \\
\hline $5-9$ баллов & 11 & 29,7 & 3 & 27,3 & 1 & 14,3 \\
\hline
\end{tabular}

Такая высокая значимость суицидальных мыслей у студентов-иностранцев требует тщательного внимания со стороны кураторов групп в аспекте предоставления необходимой помощи в адаптации, в том числе, и психоло- 
гической. За трёхлетний период исследования был один завершённый суицид. Одна попытка падения с высоты была предотвращена.

В первом случае, студентка А. (23 лет), приехала учиться в Россию по настоянию родителей, против своего желания. В преморбиде замкнутость, малообщительность, тревожность. Тяжело переживала отрыв от привычной среды, ежедневно, по несколько раз в день звонила родителям. Испытывала трудности при обучении, часто пропускала занятия. В течение первого года обучения постепенно нарастали симптомы астении (раздражительность, гиперакузия), был эпизод нарушения пищевого поведения - похудела на 7 кг. Обследование у терапевта выявило анемию. В течение месяца принимала препараты, назначенные терапевтом. От обращения в психологическую службу университета отказалась. Летние каникулы провела дома. После возвращения замкнулась, почти не общалась с одногруппниками и соседками по комнате. Начала пропускать занятия, не справлялась с учебной нагрузкой. Была допущена к сдаче зимней сессии, но сдала её неуспешно. Обострились конфликты с родителями, обнаруживала симптомы тревоги и депрессии. От вновь предложенного обращения в психологическую службу университета, консультации психотерапевта, психиатра отказалась. Во время периода повторной сдачи экзаменов выпрыгнула из окна 9 этажа, скончалась в реанимации.
Во втором случае, студент Б. (24 лет), также приехавший в Россию по настоянию родителей, не хотел учиться медицине. В преморбиде демонстративный, коммуникабельный, эгоистичный. Встречался с девушкой из Индии, с которой познакомился, приехав в Россию. Обучаясь на втором курсе, пропустил более трети занятий в первом и половины - во втором семестре, обосновывая тем, что «не интересно». Имел задолженность в зимнюю сессию, из-за которой конфликтовал с родителями. Весной мать пациента тяжело заболела, несколько недель находилась в состоянии комы. В месяц, предшествующий экзаменационной сессии, на фоне ссоры с девушкой (она упрекнула его в пропуске занятий, плохой учёбе), залез на подоконник, угрожал выпрыгнуть из окна. Сосед по комнате позвал на помощь. При помощи живших рядом, студента Б. оттащили от окна, вызвали куратора. Попросил проконсультироваться у психиатра, жаловался на «сильную усталость, чувство беспомощности». Во время беседы признался, что «не знает, что на него нашло, не хотел на самом деле покончить с собой, но из-за конфликтов с девушкой и родителями не знает, что делать». Сообщил, что в деканате готовят документы на отчисление, так как до сих пор не сдал зимнюю сессию, а возвращаться в Индию не хочет подвёл родителей. Была диагностирована тревожно-депрессивная реакция расстройства адаптации, предложена психофармакотерапия.

Таблицуа 6

Сравнительный анализ выраженности симптомов адаптационного стресса

в первые месяцы у студентов 1 курса с суицидальными мыслями и без них (критерий Манна-Уитни)

\begin{tabular}{|c|c|c|c|c|c|}
\hline \multirow[t]{2}{*}{ Симптомы учебного стресса } & \multicolumn{2}{|c|}{ Суицидальные мысли } & \multicolumn{2}{|c|}{$\begin{array}{c}\text { Без суицидальных } \\
\text { мыслей }\end{array}$} & \multirow[t]{2}{*}{$\mathrm{P}$} \\
\hline & $\mathrm{Me}$ & $\mathrm{Q}_{25-75}$ & $\mathrm{Me}$ & $\mathrm{Q}_{25-75}$ & \\
\hline Ощущение беспомощности & 3,0 & $1,0-5,0$ & 3,0 & $1,0-5,0$ & $*$ \\
\hline Наплывы посторонних мыслей & 3,0 & $0,0-5,0$ & 1,0 & $0,0-4,0$ & 0,002 \\
\hline Плохая концентрация внимания & 4,0 & $2,0-5,0$ & 3,0 & $1,0-5,0$ & $*$ \\
\hline Раздражительность, обидчивость & 2,0 & $0,0-4,0$ & 1,0 & $0,0-4,0$ & 0,003 \\
\hline Плохое настроение, депрессия & 3,0 & $1,0-5,0$ & 2,0 & $1,0-5,0$ & 0,029 \\
\hline Страх, тревога & 2,0 & $0,0-5,0$ & 1,0 & $0,0-5,0$ & 0,004 \\
\hline Потеря уверенности, снижение самооценки & 2,0 & $0,0-4,0$ & 1,0 & $0,0-2,0$ & 0,002 \\
\hline Спешка, ощущение нехватки времени & 4,0 & $1,5-7,0$ & 4,0 & $0,0-6,0$ & $*$ \\
\hline Плохой сон & 3,0 & $0,0-5,0$ & 2,0 & $0,0-4,0$ & $*$ \\
\hline Учащенное сердцебиение, боли в сердце & 0,0 & $0,0-2,0$ & 0,0 & $0,0-0,0$ & 0,012 \\
\hline Затрудненное дыхание & 0,0 & $0,0-2,0$ & 0,0 & $0,0-1,0$ & 0,001 \\
\hline Проблемы с желудочно-кишечным трактом & 0,0 & $0,0-2,5$ & 0,0 & $0,0-1,0$ & 0,012 \\
\hline Напряжение или дрожание мышц & 1,0 & $0,0-3,0$ & 0,0 & $0,0-2,0$ & 0,003 \\
\hline Головные боли & 2,0 & $0,0-5,0$ & 1,0 & $0,0-5,0$ & 0,035 \\
\hline Низкая работоспособность, утомляемость & 3,0 & $0,0-5,0$ & 2,0 & $0,0-4,0$ & 0,019 \\
\hline
\end{tabular}

Примечание: *Различия статистически не значимы 
Назначенные препараты студент Б. принимать отказался. После нескольких сеансов психотерапии и стабилизации настроения, смирился с необходимостью поездки в Индию. На учёбу после не вернулся.

При сравнении симптомов адаптационного стресса (табл. 6), установлено, что студенты с внутренними формами суицидального поведения обнаруживали более высокий уровень стресса, чем студенты без суицидальных мыслей. У них чаще выявлялись наплывы посторонних мыслей, подавленность, раздражительность, тревога, а также вегетативные симптомы - учащенное сердцебиение, затрудненное дыхание, головные боли, проблемы с желудочнокишечным трактом. Аналогичные симптомы возникали у студентов и в результате учебного стресса.

Верификация субъективной оценки сложности обучения (табл. 7) показала, что на первом курсе немногим более $40 \%$ студентов испытывали средней степени выраженности затруднения в освоении учебного материала со снижением этой цифры на 2 и 3 курсах соответственно до $28,9 \%$ и $21,6 \%\left(\chi^{2}=4,13 ; \mathrm{df}=1\right.$; $\mathrm{p}=0,042)$.

Серьёзные трудности в учёбе испытывали незначительное число студентов. Нужно отметить, что суицидальные мысли чаще встречались среди студентов, испытывающих средние и серьезные трудности во время учёбы $(\mathrm{U}=630,0 ; \mathrm{Z}=-2,16 ; \mathrm{p}=0,031)$. При этом корреляционных зависимостей между степенью выраженности суицидальных мыслей и уровнем трудности обучения выявлено не было.

Также студенты, у которых в первые месяцы имели место мысли о бессмысленности жизни и нежелании жить, были менее уверены в правильности выбора профессии ( $\mathrm{U}=504,5$; $\mathrm{Z}=-3,056 ; \mathrm{p}=0,002)$, и профессия врача потеряла для них привлекательность $(\mathrm{U}=610,0 ; \mathrm{Z}=-2,168$; $\mathrm{p}=0,03)$.

Сравнительная характеристика степени значимости учебных стрессовых факторов (табл. 8) показала, что для студентов первого курса наиболее значимыми были: отсутствие учебников, большая учебная нагрузка, нерегулярное питание, жизнь вдали от родителей, трудности в организации режима дня и проблемы при совместном проживании в общежитии с другими студентами. Степень значимости указанных стрессовых факторов у студентов первого курса была статистически значимо выше, чем у второго.

По мере адаптации, на втором и третьем курсах эти проблемы становились менее значимыми. Кроме того, у первокурсников, по сравнению со студентами 3 курса, существенное стрессогенное влияние имели страх перед будущим (неопределенность) и проблемы в личной жизни (разрыв контактов с друзьями).

Между вторым и третьим курсами статистически значимые различия выявлены по параметрам: нерациональное расписание занятий $(\mathrm{p}=0,001)$ и большое количество занятий в день $(\mathrm{p}=0,045)$, имеющих более важное значение для студентов 2 курса.

У студентов с суищидальными мыслями отмечались более значимые учебные факторы, вызывающие стресс:

- проблемы проживания в общежитии $(\mathrm{p}=0,015)$, связанные с изменением привычной обстановки, возникающими проблемами и необходимостью их самостоятельного решения, отсутствием места для уединения, высокой плотностью населения в общежитии;

- конфликты с одногруппниками $(\mathrm{p}=0,025)$, возникающие из-за разницы в мировоззрении, недостатка учебников, нежелания некоторых студентов учиться;

- разочарование в профессии врача $(\mathrm{p}=0,013)$, связанное с несовпадением представлений об обучении на первых курсах медицинского факультета и реальности;

- проблемы в личной жизни ( $\mathrm{p}=0,002)$, связанные с отрывом от привычного окружения, ссорами и конфликтами из-за невозможности встречи с близким человеком в связи с географической отдалённостью.

Таблииа 7

Субъективная оценка степени тяжести обучения

\begin{tabular}{l|c|c|c|c|c|c}
\hline \multirow{2}{*}{ Степень тяжести обучения } & \multicolumn{2}{|c|}{1 курс $(\mathrm{n}=84)$} & \multicolumn{2}{c|}{2 курс $(\mathrm{n}=45)$} & \multicolumn{2}{c}{3 курс $(\mathrm{n}=37)$} \\
\cline { 2 - 8 } & $\mathrm{n}$ & $\%$ & $\mathrm{n}$ & $\%$ & $\mathrm{n}$ & $\%$ \\
\hline Легко & 5 & 6,0 & 5 & 11,1 & 7 & 18,9 \\
\hline Незначительные трудности & 36 & 42,9 & 24 & 53,3 & 20 & 54,1 \\
\hline Средние затруднения & 36 & 42,9 & 13 & 28,9 & 8 & 21,6 \\
\hline Серьезные трудности & 7 & 8,3 & 3 & 6,7 & 2 & 5,4 \\
\hline
\end{tabular}


Значимость учебных стрессовых факторов - в баллах: от 1 до 10 (критерий Манна-Уитни)

\begin{tabular}{|c|c|c|c|c|c|c|c|c|}
\hline \multirow[t]{2}{*}{ Учебные стрессовые факторы } & \multicolumn{2}{|c|}{$\begin{array}{l}1 \text { курс } \\
(\mathrm{n}=84)\end{array}$} & \multicolumn{2}{|c|}{$\begin{array}{l}2 \text { курс } \\
(\mathrm{n}=45)\end{array}$} & \multirow{2}{*}{$\begin{array}{c}1-2 \kappa \\
p=\end{array}$} & \multicolumn{2}{|c|}{$\begin{array}{l}3 \text { курс } \\
(\mathrm{n}=37) \\
\end{array}$} & \multirow{2}{*}{$\begin{array}{c}1-3 \mathrm{~K} \\
\mathrm{p}\end{array}$} \\
\hline & $\mathrm{Me}$ & $\mathrm{Q}_{25^{-75}}$ & $\mathrm{Me}$ & $\mathrm{Q}_{25^{-75}}$ & & $\mathrm{Me}$ & $\mathrm{Q}_{25^{-75}}$ & \\
\hline Строгие преподаватели & 5,0 & $2,0-7,0$ & 5,0 & $3,0-7,0$ & $*$ & 5,0 & $3,0-6,0$ & * \\
\hline Большая учебная нагрузка & 6,0 & $4,0-8,0$ & 5,0 & $4,0-6,0$ & 0,015 & 4,0 & $3,0-6,0$ & 0,003 \\
\hline Отсутствие учебников & 7,0 & $4,0-9,0$ & 4,0 & $2,0-6,0$ & 0,0003 & 5,0 & $2,0-8,0$ & $*$ \\
\hline Непонятные, скучные учебники & 4,5 & $2,0-6,0$ & 4,0 & $1,0-5,0$ & $*$ & 3,0 & $2,0-5,0$ & 0,015 \\
\hline Жизнь вдали от родителей & 5,0 & $3,0-8,0$ & 5,0 & $2,0-6,0$ & 0,046 & 3,0 & $2,0-5,0$ & $*$ \\
\hline Нехватка денег & 3,0 & $1,0-5,0$ & 3,0 & $1,0-6,0$ & $*$ & 3,0 & $1,0-5,0$ & * \\
\hline Трудности организации режима дня & 5,0 & $3,0-7,0$ & 4,0 & $2,0-5,0$ & 0,006 & 3,0 & $1,0-5,0$ & 0,0003 \\
\hline Нерегулярное питание & 6,0 & $3,0-9,0$ & 4,0 & $2,0-6,0$ & 0,003 & 4,0 & $2,0-6,0$ & 0,003 \\
\hline Проблемы проживания в общежитии & 4,0 & $0,0-6,0$ & 1,0 & $0,0-4,0$ & 0,011 & 1,0 & $0,0-4,0$ & 0,04 \\
\hline Конфликты в группе & 2,0 & $0,0-4,0$ & 1,0 & $0,0-3,0$ & $*$ & 2,0 & $0,0-3,0$ & $*$ \\
\hline Много времени готовиться к занятиям & 5,0 & $3,0-7,0$ & 2,0 & $1,0-4,0$ & 0,0001 & 1,5 & $0,0-3,0$ & 0,0000 \\
\hline Нежелание учиться & 1,0 & $0,0-4,0$ & 2,0 & $0,0-3,0$ & $*$ & 1,0 & $0,0-3,0$ & $*$ \\
\hline Разочарование в будущей профессии & 1,0 & $0,0-3,0$ & 1,0 & $0,0-3,0$ & $*$ & 0,0 & $0,0-4,0$ & * \\
\hline Стеснительность, застенчивость & 2,0 & $0,0-5,0$ & 2,0 & $1,0-4,0$ & $*$ & 2,0 & $0,0-5,0$ & $*$ \\
\hline Страх перед будущим & 4,0 & $2,0-6,0$ & 4,0 & $1,0-5,0$ & $*$ & 2,0 & $0,0-5,0$ & 0,013 \\
\hline Проблемы в личной жизни & 3,0 & $1,0-5,0$ & 1,0 & $0,0-5,0$ & $*$ & 1,0 & $0,0-3,0$ & 0,009 \\
\hline Нерациональное расписание занятий & 5,0 & $2,0-6,0$ & 4,0 & $1,0-5,0$ & $*$ & 1,0 & $0,0-3,0$ & 0,0000 \\
\hline Много занятий в день & 5,0 & $2,0-7,0$ & 3,0 & $2,0-5,0$ & 0,02 & 2,0 & $0,0-4,0$ & 0,0000 \\
\hline Отработка пропущенных занятий & 4,0 & $1,0-6,0$ & 3,0 & $1,0-6,0$ & $*$ & 4,0 & $1,0-7,0$ & $*$ \\
\hline
\end{tabular}

Примечание: *Различия статистически не значимы

Факторный анализ (с varimax вращением фактора) выявил 6 значимых факторов (табл. 9) учебного стресса для студентов первого курса (68,8\% дисперсии). Установлено, что наиболее значимым стрессовым фактором был напряженный график учёбы и определённая растерянность, своего рода разочарование в профессии в силу непонимания на первых порах взаи- мосвязи между общеобразовательными дисциплинами и врачебной профессией. Наряду с этим большое значение имели трудности в освоении учебного материала, сложности в планировании режима дня. Отдельно следует сказать о тоске по дому и проблемах в адаптации к совместному проживанию в общежитии в одной комнате с другими студентами.

Таблийа 9

Наиболее значимые факторы учебного стресса для иностранных студентов 1 курса

\begin{tabular}{l|l|c}
\hline \multicolumn{1}{c|}{ Наименование фактора } & \multicolumn{1}{c}{ Составляющие фактора } & $\begin{array}{c}\text { \% } \\
\text { дисперсии }\end{array}$ \\
\hline \multirow{2}{*}{ Напряженный график учёбы } & Строгие преподаватели $(0,875)$ & \multirow{2}{*}{27,7} \\
\cline { 2 - 2 } & Большая нагрузка $(0,866)$ & \\
\cline { 2 - 3 } & Много готовить $(0,723)$ & \multirow{2}{*}{7,5} \\
\hline Разочарование & Разочарование в профессии $(0,869)$ \\
\hline Трудности в усвоении учебного материала & Непонятные учебники $(0,761)$ & \multirow{2}{*}{7,6} \\
\hline \multirow{2}{*}{$\begin{array}{l}\text { Трудности планирования режима труда и } \\
\text { отдыха }\end{array}$} & Нерациональное расписание $(0,844)$ & 6,3 \\
\cline { 2 - 3 } & Трудности режима дня $(0,762)$ & 5,8 \\
\hline Тоска по дому & Жизнь вдали от родителей $(0,821)$ & \\
\hline Бытовой стресс & Проблемы совместного проживания в общежитии & \\
\hline
\end{tabular}


Структура и выраженность (в баллах: от 1 до 10) симптомов учебного стресса (критерий Манна-Уитни)

\begin{tabular}{|c|c|c|c|c|c|c|c|c|}
\hline \multirow[t]{2}{*}{ Симптомы учебного стресса } & \multicolumn{2}{|c|}{$\begin{array}{l}1 \text { курс } \\
(\mathrm{n}=84)\end{array}$} & \multicolumn{2}{|c|}{$\begin{array}{l}2 \text { курс } \\
(\mathrm{n}=45)\end{array}$} & \multirow{2}{*}{$\begin{array}{c}1-2 \\
\text { курс } \\
\mathrm{p}=\end{array}$} & \multicolumn{2}{|c|}{$\begin{array}{l}3 \text { курс } \\
(\mathrm{n}=37)\end{array}$} & \multirow{2}{*}{$\begin{array}{c}1-3 \text { курс } \\
\text { p }\end{array}$} \\
\hline & $\mathrm{Me}$ & $\mathrm{Q}_{25-75}$ & $\mathrm{Me}$ & $\mathrm{Q}_{25-75}$ & & $\mathrm{Me}$ & $\mathrm{Q}_{25-75}$ & \\
\hline Ощущение беспомощности & 3,0 & $1,0-5,0$ & 2,0 & $0,0-4,0$ & $*$ & 1,0 & $0,0-3,0$ & 0,0016 \\
\hline Наплывы посторонних мыслей & 3,0 & $1,0-5,0$ & 2,0 & $1,0-4,0$ & $*$ & 1,0 & $0,0-3,0$ & 0,0062 \\
\hline Плохая концентрация внимания & 4,0 & $1,0-5,0$ & 3,0 & $1,0-5,0$ & $*$ & 1,0 & $0,0-2,0$ & 0,0001 \\
\hline Раздражительность, обидчивость & 3,0 & $0,0-4,5$ & 2,0 & $0,0-4,0$ & $*$ & 1,0 & $0,0-3,0$ & 0,0338 \\
\hline Плохое настроение, депрессия & 3,0 & $1,0-5,0$ & 2,0 & $1,0-4,0$ & $*$ & 1,0 & $0,0-2,0$ & 0,0033 \\
\hline Страх, тревога & 3,0 & $1,0-5,0$ & 1,0 & $0,0-3,0$ & 0,0008 & 1,0 & $0,0-2,0$ & 0,0013 \\
\hline Потеря уверенности, снижение самооценки & 2,0 & $0,0-5,0$ & 1,0 & $0,0-3,0$ & $*$ & 1,0 & $0,0-2,0$ & 0,0180 \\
\hline Спешка, ощущение нехватки времени & 4,0 & $2,0-7,0$ & 3,0 & $1,0-5,0$ & 0,022 & 1,0 & $0,0-4,0$ & 0,0002 \\
\hline Плохой сон & 4,0 & $1,0-6,0$ & 3,0 & $0,0-6,0$ & $*$ & 2,0 & $0,0-4,0$ & 0,0025 \\
\hline Проблемы в общении с преподавателями & 2,0 & $0,0-5,0$ & 2,0 & $0,0-4,0$ & $*$ & 3,0 & $1,0-5,0$ & $*$ \\
\hline Учащенное сердцебиение, боли в сердце & 0,0 & $0,0-3,0$ & 0,0 & $0,0-1,0$ & $*$ & 0,0 & $0,0-1,0$ & $*$ \\
\hline Затрудненное дыхание & 0,0 & $0,0-3,0$ & 0,0 & $0,0-1,0$ & $*$ & 0,0 & $0,0-1,0$ & $*$ \\
\hline Проблемы с желудочно-кишечным трактом & 0,0 & $0,0-3,0$ & 0,0 & $0,0-1,0$ & $*$ & 0,0 & $0,0-1,0$ & $*$ \\
\hline Напряжение или дрожание мышц & 1,0 & $0,0-3,0$ & 0,0 & $0,0-2,0$ & $*$ & 0,0 & $0,0-1,0$ & $*$ \\
\hline Головные боли & 3,0 & $1,0-6,0$ & 2,0 & $0,0-3,0$ & $*$ & 1,0 & $0,0-2,0$ & 0,002 \\
\hline Низкая работоспособность, утомляемость & 3,0 & $1,0-6,0$ & 1,0 & $0,0-3,0$ & 0,004 & 0,0 & $0,0-2,0$ & 0,0000 \\
\hline
\end{tabular}

Примечание: *Различия статистически не значимы

Сравнительный анализ степени выраженности симптомов учебного стресса (табл. 10) показал, что для студентов первого курса, по сравнению со вторым, наиболее выраженными были спешка, ощущение нехватки времени, страх и тревога, а также низкая работоспособность. Значимыми симптомами для 1 и 2 курсов были плохой сон и расстройства внимания.

Необходимо отметить, что перечисленные симптомы тесно взаимосвязаны и входят в структуру депрессивного и тревожнодепрессивного синдромов, являющихся психопатологической основой суицидального пове- дения $[31,32,33]$. Целесообразно их раннее выявление и коррекция, которые возможны при реализации в рамках «дисциплин по выбору» программы стресс-менеджмента, направленной на обучение студентов конструктивным приёмам преодоления стресса (способы разрешения конфликтов, преодоления ауто- и гетероагрессивных тенденций, методы релаксации и др.), грамотному планированию времени, методам оптимальной самостоятельной работы с учебной литературой, информирование о здоровом образе жизни с учётом биоритмов, режима дня и особенностей питания.

Таблича 11

Наиболее значимые факторы симптомов учебного стресса для иностранных студентов 1 курса

\begin{tabular}{|c|c|c|}
\hline Наименование фактора & Составляющие фактора & $\begin{array}{c}\% \\
\text { дисперсии }\end{array}$ \\
\hline \multirow{7}{*}{ Астеническая субдепрессия } & Ощущение беспомощности $(0,799)$ & \multirow{7}{*}{42,3} \\
\hline & Наплывы посторонних мыслей $(0,829)$ & \\
\hline & Плохая концентрация внимания $(0,736)$ & \\
\hline & Плохое настроение, депрессия $(0,717)$ & \\
\hline & Страх, тревога $(0,775)$ & \\
\hline & Потеря уверенности, снижение самооценки $(0,733)$ & \\
\hline & Спешка, ощущение нехватки времени $(0,821)$ & \\
\hline \multirow{4}{*}{ Психосоматические симптомы } & Учащенное сердцебиение, боли в сердце $(0,861)$ & \multirow{4}{*}{15,8} \\
\hline & Затрудненное дыхание $(0,795)$ & \\
\hline & Проблемы с желудочно-кишечным трактом $(0,832)$ & \\
\hline & Головные боли $(0,728)$ & \\
\hline
\end{tabular}


Результаты теста GAD-7

\begin{tabular}{l|c|c|c|c|cc|c}
\hline \multirow{2}{*}{$\begin{array}{c}\text { Степень } \\
\text { выраженности }\end{array}$} & \multicolumn{2}{c|}{1 курс } & \multicolumn{2}{c|}{2 курс } & \multicolumn{2}{c}{3 курс } \\
\cline { 2 - 8 } & $\mathrm{n}$ & $\%$ & $\mathrm{n}$ & $\%$ & $\mathrm{n}$ & $\%$ \\
\hline $0-$ None & 37 & 44,0 & 31 & 69,0 & 22 & 59,5 \\
\hline $1-$ Mild & 34 & 40,5 & 11 & 24,0 & 10 & 27,0 \\
\hline $2-$ Moderate & 12 & 14,3 & 3 & 7,0 & 5 & 13,5 \\
\hline $3-$ Severe & 1 & 1,2 & 0 & 0,0 & 0 & 0,0 \\
\hline
\end{tabular}

Большинство психологических (ощущение беспомощности, наплывы посторонних мыслей, плохая концентрация внимания, раздражительность, обидчивость, плохое настроение, потеря уверенности, снижение самооценки, головные боли и низкая работоспособность) симптомов стресса были одинаково значимыми для студентов 1 и 2 курсов. Их значимость для третьекурсников статистически значимо снизилась.

При сравнении степени выраженности симптомов учебного стресса между студентами 2 и 3 курсов статистически значимые $(\mathrm{p}=0,004)$ различия выявлены по параметру расстройство внимания (более выраженное у второкурсников).

Сравнительный анализ значимости факторов показал, что для студентов 1 курса с суицидальными мыслями были более актуальны, чем для студентов без суицидальных мыслей, возникающие в ответ на факторы учебного стресса, страх и тревога $(\mathrm{p}=0,04)$, и их вегетативные проявления - учащенное сердцебиение и боли в сердце $(\mathrm{p}=0,006)$, затруднённое дыха- ние $(\mathrm{p}=0,004)$, проблемы с пищеварением $(\mathrm{p}=0,0005)$, головные боли $(\mathrm{p}=0,013)$.

Факторный анализ выявил 2 значимых фактора (табл. 11), отражающих симптомы учебного стресса у студентов 1 курса $(58,1 \%$ дисперсии).

Обследование при помощи теста GAD-7 показало (таблица 12), что наибольшее число симптомов ГТР регистрировалось у студентов 1 курса - более чем половины (56\%) со снижением $\left(\chi^{2}=6,29 ; \mathrm{df}=1 ; \mathrm{p}=0,013\right)$ на втором $(31 \%)$ и незначительным повышением на третьем $(40,5 \%)$. Повышение уровня тревоги на третьем курсе обусловлено началом обучения на клинических кафедрах, требующего общения и обследования пациентов при недостаточном знании русского языка (и недостатке пациентов, владеющих английским языком). Более того $(\mathrm{OR}=2,8 ; 95 \%$; $\mathrm{CI}=1,2-6,5)$, обучение на 1 курсе сопряжено с риском возникновения генерализованной тревоги более чем в 2,5 раза, чем на втором курсе.

Результаты теста DASS-21

Таблица 13

\begin{tabular}{|c|c|c|c|c|c|c|}
\hline \multirow{2}{*}{$\begin{array}{c}\text { Степень } \\
\text { выраженности }\end{array}$} & \multicolumn{2}{|c|}{1 курс } & \multicolumn{2}{|c|}{2 курс } & \multicolumn{2}{|c|}{3 курс } \\
\hline & $\mathrm{n}$ & $\%$ & $\mathrm{n}$ & $\%$ & $\mathrm{n}$ & $\%$ \\
\hline \multicolumn{7}{|c|}{ Депрессия } \\
\hline Норма & 58 & 69,0 & 37 & 82,2 & 33 & 89,2 \\
\hline Легко & 10 & 11,9 & 3 & 6,7 & 2 & 5,4 \\
\hline Умеренная & 14 & 16,7 & 5 & 11,1 & 1 & 2,7 \\
\hline Выраженная & 2 & 2,4 & 0 & 0,0 & 1 & 2,7 \\
\hline \multicolumn{7}{|c|}{ Тревога } \\
\hline Норма & 42 & 50,0 & 29 & 64,4 & 24 & 64,9 \\
\hline Легко & 15 & 17,9 & 8 & 17,8 & 4 & 10,8 \\
\hline Умеренная & 10 & 11,9 & 5 & 11,1 & 5 & 13,5 \\
\hline Выраженная & 6 & 7,1 & 2 & 4,4 & 2 & 5,4 \\
\hline Тяжелая & 10 & 11,9 & 1 & 2,2 & 2 & 5,4 \\
\hline \multicolumn{7}{|c|}{ Стресс } \\
\hline Норма & 59 & 70,2 & 38 & 84,4 & 33 & 89,2 \\
\hline Легко & 9 & 10,7 & 3 & 6,7 & 1 & 2,7 \\
\hline Умеренная & 14 & 16,7 & 4 & 8,9 & 2 & 5,4 \\
\hline Выраженная & 2 & 2,4 & 0 & 0,0 & 1 & 2,7 \\
\hline
\end{tabular}


Приёмы устранения (в баллах: от 1 до 10) симптомов учебного стресса (критерий Манна-Уитни)

\begin{tabular}{|c|c|c|c|c|c|c|c|c|}
\hline \multirow{2}{*}{$\begin{array}{c}\text { Способы преодоления учебного } \\
\text { стресса }\end{array}$} & \multicolumn{2}{|c|}{1 курс } & \multicolumn{2}{|c|}{2 курс } & \multirow{2}{*}{$\begin{array}{c}1-2 \text { курс } \\
\mathrm{p}=\end{array}$} & \multicolumn{2}{|c|}{3 курс } & \multirow{2}{*}{$\begin{array}{c}1-3 \text { курс } \\
\mathrm{p}\end{array}$} \\
\hline & $\mathrm{Me}$ & $\mathrm{Q}_{25-75}$ & $\mathrm{Me}$ & $\mathrm{Q}_{25^{-} 75}$ & & $\mathrm{Me}$ & $\mathrm{Q}_{25^{-} 75}$ & \\
\hline Употребление алкоголя & 0,0 & $0,0-0,0$ & 0,0 & $0,0-1,0$ & $*$ & 0,0 & $0,0-1,0$ & $*$ \\
\hline Табакокурение & 0,0 & $0,0-1,0$ & 0,0 & $0,0-0,0$ & $*$ & 0,0 & $0,0-1,0$ & $*$ \\
\hline Употребляют наркотики & 0,0 & $0,0-0,0$ & 0,0 & $0,0-0,0$ & $*$ & 0,0 & $0,0-0,0$ & $*$ \\
\hline Употребляю больше еды & 3,0 & $0,0-5,0$ & 2,0 & $0,0-5,0$ & $*$ & 1,0 & $0,0-4,0$ & 0,028 \\
\hline Смотрят телевизор & 2,0 & $0,0-4,0$ & 3,0 & $1,0-6,0$ & 0,005 & 2,0 & $0,0-4,0$ & $*$ \\
\hline Пропуски занятий & 1,0 & $0,0-3,0$ & 1,0 & $0,0-3,0$ & $*$ & 1,0 & $0,0-2,0$ & $*$ \\
\hline Больше сплю & 3,0 & $0,0-6,0$ & 3,0 & $2,0-6,0$ & $*$ & 2,0 & $1,0-4,0$ & $*$ \\
\hline Общение с друзьями & 4,0 & $2,0-6,0$ & 5,0 & $3,0-6,0$ & $*$ & 5,0 & $2,0-6,0$ & $*$ \\
\hline Поддержка родителей & 5,0 & $3,0-8,0$ & 6,0 & $4,0-9,0$ & $*$ & 7,0 & $4,0-9,0$ & $*$ \\
\hline Прогулки на воздухе & 5,0 & $3,0-8,0$ & 6,0 & $4,0-8,0$ & $*$ & 6,0 & $5,0-8,0$ & 0,049 \\
\hline Занимались спортом & 3,0 & $0,0-5,0$ & 5,0 & $3,0-8,0$ & 0,0002 & 5,0 & $3,0-7,0$ & 0,002 \\
\hline Посещаю бассейн & 2,0 & $0,0-6,0$ & 5,0 & $3,0-9,0$ & 0,002 & 3,0 & $1,0-9,0$ & 0,046 \\
\hline Компьютерные игры & 1,5 & $0,0-5,0$ & 3,0 & $0,0-5,0$ & $*$ & 3,0 & $1,0-5,0$ & $*$ \\
\hline Интернет & 4,0 & $2,0-6,0$ & 5,0 & $3,0-6,0$ & $*$ & 5,0 & $3,0-6,0$ & $*$ \\
\hline Читают художественную литературу & 3,0 & $0,0-5,0$ & 3,0 & $1,0-5,0$ & $*$ & 2,0 & $1,0-4,0$ & $*$ \\
\hline Лекарственные настойки & 0,0 & $0,0-2,0$ & 1,0 & $0,0-3,0$ & $*$ & 0,0 & $0,0-2,0$ & $*$ \\
\hline Принимают лекарства & 0,5 & $0,0-4,0$ & 1,0 & $0,0-2,0$ & $*$ & 0,0 & $0,0-3,0$ & $*$ \\
\hline
\end{tabular}

Примечание: *Различия статистически не значимы

Анализ степень выраженности депрессии, тревоги и стресса (тест DASS-21) показал (табл. 13), что у студентов 1 курса депрессия была у $31 \%$, у второго $-17,8 \%\left(\chi^{2}=6,3 ; \mathrm{df}=1\right.$; $\mathrm{p}=0,013)$ и у третьего $-10,8 \%$. Вероятность развития депрессии $(\mathrm{OR}=2,6 ; 95 \% \mathrm{CI}=1,2-5,7)$ у студентов 1 курса более чем в 2,5 раза выше, чем у второго.

Тревога различной степени выраженности наблюдалась у $50 \%$ студентов первого, $35,6 \%$ второго и $35,1 \%$ третьего курсов (различия статистически не значимы).

Наибольшее число - 29,8\% молодых людей, испытывающих стресс, было среди студентов первого курса со снижением на втором - до $15,6 \%$ и на третьем - до $10,8 \%$ (по сравнению с первым: $\left.\chi^{2}=4,08 ; \mathrm{df}=1 ; \mathrm{p}=0,044\right)$. Отношение шансов (OR=3,5; 95\% CI=1,0-13,0) свидетельствует, что обучение на первом курсе медицинского ВУЗа является фактором риска, более чем в 3 раза повышающее возможность возникновения стрессового напряжения.

Полученные данные совпадают с ранее проведёнными исследованиями $[34,35,36]$ и подтверждают тот факт, что выраженность тревоги, депрессии и стрессового напряжения среди студентов-медиков максимальна на первом курсе и постепенно снижается к третьему, что свидетельствует об адаптации к учебному процессу и клинической работе.
Сравнительный анализ приёмов преодоления стресса студентами 1-3 курсов представлен в таблице 14.

Можно отметить, что студенты 2 курса достоверно чаще, чем первокурсники, для преодоления учебного стресса занимались спортом и смотрели телевизор, преимущественно на родном или английском языках. При этом преобладал просмотр фантастических и детективных сериалов, а также различных развлекательных программ, что мало способствовало адаптации к новой среде. Для студентов первого курса было более характерно переедание как способ преодоления учебного стресса, а третьекурсники чаще занимались спортом. Статистически значимых различий между 2 и 3 курсами не выявлено, что может отражать переходный этап адаптации.

Значительная часть - 19\% студентов первого курса (табл. 15), для преодоления стресса употребляли алкогольные напитки, а со степенью значимости этого способа в 3-6 баллов - 9 $(10,7 \%)$ человек. Среди студентов 2 курса со степенью значимости 3-5 баллов было 3 (6,7\%) человека. Студенты 3 курса употребляли алкоголь статистически значимо чаще $\left(\chi^{2}=6,54\right.$; $\mathrm{df}=1 ; \mathrm{p}=0,011)$, чем первого - соответственно $43,2 \%$ и $19 \%$. Кроме того, нередко отмечалось употребление наркотиков и табакокурение. 
Химические аддикции, как способ преодоления стресса

\begin{tabular}{l|c|c|c|c|c|c}
\hline \multirow{2}{*}{ Вещество } & \multicolumn{2}{c|}{1 курс $(\mathrm{n}=84)$} & \multicolumn{2}{c|}{2 курс $(\mathrm{n}=45)$} & \multicolumn{3}{c}{3 курс $(\mathrm{n}=37)$} \\
\cline { 2 - 8 } & $\mathrm{n}$ & $\%$ & $\mathrm{n}$ & $\%$ & $\mathrm{n}$ & $\%$ \\
\hline Табак & 25 & 29,8 & 9 & 20,1 & 13 & 35,1 \\
\hline Алкоголь & 16 & 19,0 & 14 & 31,1 & 16 & 43,2 \\
\hline Наркотики & 11 & 13,1 & 8 & 17,8 & 2 & 5,4 \\
\hline $\begin{array}{l}\text { Лекарственные настойки и нерецептурные } \\
\text { седативные препараты }\end{array}$ & 52 & 63,4 & 28 & 62,2 & 20 & 54,1 \\
\hline
\end{tabular}

Кроме того, более половины студентов на всех курсах принимали седативные лекарственные настойки и нерецептурные седативные препараты. Такой высокий удельный вес применения химических веществ для преодоления стресса является фактором риска формирования аддиктивного поведения и зависимостей. При этом студенты, у которых возникали мысли о нежелании жить в период адаптации, чаще, чем лица без суицидальных мыслей, принимали настои трав $(\mathrm{p}=0,002)$ и нерецептурные седативные препараты $(\mathrm{p}=0,016)$ для преодоления стрессового напряжения. Кроме того, значительная часть молодых людей в силу стресса употребляли больше пищи. Так со степенью значимости этого способа в 610 баллов на 1 курсе было 21,5\% студентов, на втором - 20,0\%, на третьем - 10,8\%.

Установлено, что у студентов 1 курса, употребляющих алкоголь и наркотики, в период адаптации были более выражены страх и беспокойство, чем у непринимающих ( $\mathrm{U}=397$; $\mathrm{p}=0,0033)$. Они чаще намеренно пропускали занятия ( $\mathrm{U}=412,5 ; \mathrm{p}=0,006)$, поэтому имели задолженности с необходимостью отработки пропусков $(\mathrm{U}=435 ; \mathrm{p}=0,014)$. Последнее вызывало у них бо̀льший стресс, чем у непринимающих алкоголь и наркотики. Они больше спали в выходные дни $(\mathrm{U}=471 ; \mathrm{p}=0,029)$, больше гуляли и позже возвращались домой $(\mathrm{U}=1245,5 ; \mathrm{p}=0,0009)$. Кроме того, они чаще $(\mathrm{U}=311,5 ; \mathrm{p}=0,038)$, чем неупотребляющие алкоголь и наркотики, испытывали негативное влияние на взаимодействие с другими людьми из-за религии.

С целью профилактики суицидального поведения иностранных студентов, формирующегося в связи с социально-психологической дезадаптацией, связанной с высоким уровнем тревожности в первые месяцы адаптации, за каждой группой закреплен куратор из числа преподавателей. В задачи куратора входит знакомство студентов с особенностями культуры страны пребывания, правилами внутреннего трудового распорядка учебного заведения, знакомство с основными правилами общежития, помощь в решении бытовых вопросов и ряд других.

Заключение.

Таким образом, в результате исследования установлено, что студенты-иностранцы, приезжающие в Россию для обучения медицине, в периоде адаптации переживают стрессовое напряжение, в значимом числе случаев (до $44 \%)$ приводящее к возникновению внутренних форм суицидального поведения. В то же время при ретроспективой оценке (через годдва) студентами эта цифра значительно снижается, что обусловлено успешным приспособлением большинства обучающихся к новым условиям жизни и снижением актуальности прежних проблем в адаптации. У студентов с внутренними формами суицидального поведения обнаруживается более высокий уровень стресса, астенический и тревожно - субдепрессиный синдромы, чем у студентов без суицидальных мыслей. Также, студенты, у которых в первые месяцы учёбы били мысли о бессмысленности жизни и нежелании жить, были менее уверены в правильности выбора профессии врача, которая потеряла для них привлекательность.

Для студентов с суицидальным поведением особенно значимыми были проблемы совместного проживания в общежитии, конфликты с одногруппниками, разочарование в профессии врача и проблемы в личной жизни.

Для преодоления стресса студенты 2 и 3 курсов чаще выбирали занятие спортом, чем первокурсники, а те, для кого были характерны суицидальные переживания, чаще выбирали пассивные способы - употребление настоев трав и нерецептурных седативных препаратов. С 1 по 3 курс наблюдается рост числа иностранных студентов, употребляющих алкоголь и прибегающих к табакокурению. 
Профилактика состояний социальнопсихологической дезадаптации, аддиктивного и суицидального поведения, требует разработки программы стресс-менеджмента. Такая программа должна являться частью учебного процесса, реализовываться в рамках «дисциплин по выбору», иметь теоретический и практический (тренинговый) блоки и решать следующие задачи:

1. Обучение студентов грамотному планированию времени, знакомство с основными требованиями к учебному процессу. Уделяется внимание методам оптимальной самостоятельной работы с учебной литературой, развитие навыков самопрезентации и осведомленности в этапах построения карьеры.

2. Информирование студентов о миграционном и учебном стрессе; обучение приёмам

Литература:

1. Mori S. Addressing the Mental Health Concerns of International Students. Journal of Counseling and Development. 2000; 78 (2): 137-44.

2. Rice G.H., Dellwo J.P. Perfectionism and Self-Development Implications for College Adjustment. Journal of Counseling and Development. 2002; 80 (2): 188-196.

3. Булгакова Я.В., Семилетова В.А., Натарова А.А. Мотивационные особенности российских и иностранных студентов при адаптации к учебному процессу. Организационные и методические основы учебно-воспитательной работы в медииинском ВУЗе. 2010; 2: 186-7.

4. Кошелева Е.Ю., Амартей Дж.А. Влияние факторов стресса на адаптацию к академическому процессу в российском вузе иностранных и российских студентов. Альманах современной науки и образования. 2015; 4: 95-8.

5. Wang C.C., Andre K., Greenwood K.M. Chinese students studying at Australian universities with specific reference to nursing students: a narrative literature review. Nurse Educ. Today. 2015; 35 (4): 609-619.

6. Камара Ишака. Иностранные студенты в российском вузе социокультурные особенности адаптации и профессиональной социализации: Автореф. дис. ... канд. социол. наук. Краснодар, 2014. 27 c.

7. Миронов С.В. Состояние здоровья российских и иностранных студентов медицинского ВУЗа и пути улучшения их медицинского обслуживания: Автореф. дис. ... канд. мед. наук. M., 2014. 25 c.

8. Radcliffe C., Lester H. Perceived stress during undergraduate medical training: a qualitative study. Med. Educ. 2003; 37 (1): 32-38.

9. Vaez M. Health and quality of life during years at university, studies on their development and determinants: PhD Thesis. Stockholm, 2004. $62 \mathrm{p}$

10. Руженков В.А., Руженкова В.В. Некоторые аспекты суицидального поведения учащейся молодежи и возможные пути предупреждения. Сибирский вестник психиатрии и наркологии. 2011; 4: 52-54. разрешения конфликтов, преодоления стрессового напряжения и способам адаптации в микросоциальном окружении, преодоления ауто- и гетероагрессивных тенденций, методам релаксации и др. Особое внимание должно уделяться студентам, склонным к депрессивным реакциям и формированию внутренних форм суицидального поведения.

3. Информирование о здоровом образе жизни с учётом биоритмов, режима дня и особенностей питания, конструктивных методах борьбы со стрессом.

Реализация такой программы будет способствовать преодолению миграционного и учебного стресса, улучшит адаптационные возможности.

Reference:

1. Mori S. Addressing the Mental Health Concerns of International Students. Journal of Counseling and Development. 2000; 78 (2): $137-44$.

2. Rice G.H., Dellwo J.P. Perfectionism and Self-Development: Implications for College Adjustment. Journal of Counseling and Development. 2002; 80 (2): 188-196.

3. Bulgakova YA.V., Semiletova V.A., Natarova A.A. Motivatsionnye osobennosti rossijskikh i inostrannykh studentov pri adaptatsii k uchebnomu protsessu [Motivational features of Russian and foreign students in adapting to the educational process]. Organizatsionnye i metodicheskie osnovy uchebno-vospitatel'noj raboty $v$ meditsinskom VUZe [Organizational and methodical bases of educational work in medical University]. 2010; 2: 1867. (In Russ)

4. Kosheleva E. YU., Amartej Dzh. A. Vliyanie faktorov stressa na adaptatsiyu $\mathrm{k}$ akademicheskomu protsessu $\mathrm{v}$ rossijskom vuze inostrannykh i rossijskikh studentov [Influence of stress factors on adaptation to the academic process in the Russian University of foreign and Russian students]. Al'manakh sovremennoj nauki obrazovaniya [Almanac of modern science and education]. 2015; 4: 95-8. (In Russ)

5. Wang C.C., Andre K., Greenwood K.M. Chinese students studying at Australian universities with specific reference to nursing students: a narrative literature review. Nurse Educ. Today. 2015; 35 (4): 609-619.

6. Kamara Ishaka. Inostrannye studenty $\mathrm{v}$ rossijskom vuze sotsiokul'turnye osobennosti adaptatsii i professional'noj sotsializatsii [Foreign students in the Russian University: sociocultural features of adaptation and professional socialization]: avtoref. dis. ... kand. sotsiol. nauk. Krasnodar, 2014. 27 s. (In Russ)

7. Mironov S.V. Sostojanie zdorov,ja rossijskih i inostrannyh studentov medicinskogo vuza i puti uluchshenija ih medicinskogo obsluzhivanija [State of health of Russian and foreign medical students and ways to improve their medical care]: avtoref. dis. ... kand. med. nauk. M., 2014. 25 s. (In Russ)

8. Radcliffe C., Lester H. Perceived stress during undergraduate medical training: a qualitative study. Med. Educ. 2003; 37 (1): 32-38.

9. Vaez M. Health and quality of life during years at university, studies on their development and determinants: PhD. Thesis. Stockholm, 2004. $62 \mathrm{p}$

10. Ruzhenkov V.A., Ruzhenkova V.V. Nekotorye aspekty suicidal,nogo povedenija uchawejsja molodezhi i vozmozhnye puti preduprezhdenija [Some aspects of suicidal behavior of students and possible ways of prevention]. Sibirskij vestnik psihiatrii $i$ narkologii [Siberian journal of psychiatry and narcology]. 2011; 4: 52-4. (In Russ) 
11. Rosiek A., Rosiek-Kryszewska A., Leksowski Ł., Leksowski K Chronic stress and suicidal thinking among medical students. Int. J. Environ Res. Public Health. 2016; 13 (2): Art. 212. URL: http://www.mdpi.com/1660-4601/13/2/212/htm

12. Yusoff M.S., Abdul Rahim A.F., Baba A.A., Ismail S.B., Mat Pa M.N., Esa A.R. Prevalence and associated factors of stress, anxiety and depression among prospective medical students. Asian J. Psychiatr. 2013; 6 (2): 128-133.

13. Хритинин Д.Ф., Сумарокова М.А., Есин А.В., Самохин Д.В., Щукина Е.П. Условия формирования суицидального поведения у студентов медицинского ВУЗа. Суицицдология. 2016; 7 (2): 49-54.

14. Зотов П.Б. Психотерапия суицидального поведения: возрастной аспект. Академический журнал Западной Сибири. 2013; 9 (3): $52-54$

15. Abdulghani H.M., Al Kanhal A.A., Mahmoud E.S., Ponnamperuma G.G., Alfaris E.A. Stress and its effects on medical students: a cross-sectional study at a college of medicine in Saudi Arabia. J. Health Popul. Nutr. 2011; 29 (5): 516-522.

16. Saeed A.A., Bahnassy A.A., Al-Hamdan N.A., Almudhaibery F.S., Alyahya A.Z Perceived stress and associated factors among medical students. J. Family Community Med. 2016; 23 (3): 166171.

17. Burger P.H.M., Scholz M. Gender as an underestimated factor in mental health of medical students. Ann. Anat. 2018; 218: 1-6.

18. Setko N.P., Bulycheva E.V., Beilina E.B. Hygienic estimation of functional reserves and adaptive capabilities of students. Gig. Sanit. 2017; 96 (2): 166-170.

19. Al-Kaabba A.F., Saeed A.A., Abdalla A.M., Hassan H.A., Mustafa A.A. Prevalence and associated factors of cigarette smoking among medical students at King Fahad Medical City in Riyadh of Saudi Arabia. J. Family Community Med. 2011; 18 (1): 8-12.

20. Melaku L., Mossie A., Negash A. Stress among Medical Students and Its Association with Substance Use and Academic Performance. J. Biomed. Educ. 2015; 2015: Art. 149509. URL: https://www.hindawi.com/journals/jbe/2015/149509/.

21. Silva V., Costa P., Pereira I., Faria R., Salgueira A.P., Costa M.J., Sousa N., Cerqueira J.J., Morgado P. Depression in medical students: insights from a longitudinal study. BMC Med. Educ. 2017; 17 (1): 184.

22. Egnew T.R., Lewis P.R., Schaad D.C., Karuppiah S., Mitchell S Medical student perceptions of medical school education about suffering: a multicenter pilot study. Fam. Med. 2014; 46 (1): 3944.

23. Chen L., Zhao R.L., Chen H. Association between coping styles and non-suicidal self-injury among undergraduate students in Wuhan. Zhonghua Liu Xing Bing Xue Za Zhi. 2017; 38 (12): 1607-1610.

24. Dunn L.B., Iglewicz A., Moutier C. A conceptual model of medical student well-being: promoting resilience and preventing burnout. Acad. Psychiatry. 2008; 32 (1): 44-53.

25. Chang E., Eddins-Folensbee F., Coverdale J. Survey of the prevalence of burnout, stress, depression, and the use of supports by medical students at one school. Acad. Psychiatry. 2012; 36 (3): 177-182

26. Egnew T.R., Lewis P.R., Meyers K.R., Phillips W.R. The suffering medical students attribute to their undergraduate medical education. Fam. Med. 2018; 50 (4): 296-299.

27. Щербатых Ю.В. Психология стресса. М.: Эксмо, 2006. 304 с.

28. Spitzer R.L., Kroenke K., Williams J.B.W., Lowe B. A brief measure for assessing generalized anxiety disorder. Arch. Intern. Med. 2006; 166 (10): 1092-1097.

29. Lovibond P.F, Lovibond S.H. The structure of negative emotional states: comparison of the Depression Anxiety Stress Scales (DASS) with the beck depression and anxiety inventories. Behav. Res. Ther. 1995; 33: 335-342.

30. Васильева Л.Н., Щепеткова С.С. О суицидальном риске у студентов-медиков. Историческая и сочиально - образовательная мысль. 2015; 7 (3): 179-183.

31. Nasrallah H. A., Smeltzer D. J. Contemporary diagnosis and management of the patient with schizophrenia. Newtown, Pa: Handbooks in Health Care Co., 2002. 248 p.
11. Rosiek A., Rosiek-Kryszewska A., Leksowski Ł., Leksowski K Chronic stress and suicidal thinking among medical students. Int J. Environ Res. Public Health. 2016; 13 (2): Art. 212. URL http://www.mdpi.com/1660-4601/13/2/212/htm

12. Yusoff M.S., Abdul Rahim A.F., Baba A.A., Ismail S.B., Mat Pa M.N., Esa A.R. Prevalence and associated factors of stress, anxiety and depression among prospective medical students. Asian $J$. Psychiatr. 2013; 6 (2): 128-33.

13. Chritinin D.F., Sumarokova M.A., Esin A.V., Samokhin D.V., Shchukina E.P. Conditions of suicidal behavior formation among medical college students. Suicidology. 2016; 7 (2): 49-54. (In Russ)

14. Zotov P.B. Psychotherapy of suicidal behavior in different age groups. Academic Journal of West Siberia. 2013; 9 (3): 52-54. (In Russ)

15. Abdulghani H.M., Al Kanhal A.A., Mahmoud E.S., Ponnamperuma G.G., Alfaris E.A. Stress and its effects on medical students: a cross-sectional study at a college of medicine in Saudi Arabia. J. Health Popul. Nutr. 2011; 29 (5): 516-522.

16. Saeed A.A., Bahnassy A.A., Al-Hamdan N.A., Almudhaibery F.S., Alyahya A.Z Perceived stress and associated factors among medical students. J. Family Community Med. 2016; 23 (3): 166171.

17. Burger P.H.M., Scholz M. Gender as an underestimated factor in mental health of medical students. Ann. Anat. 2018; 218: 1-6.

18. Setko N.P., Bulycheva E.V., Beilina E.B. Hygienic estimation of functional reserves and adaptive capabilities of students. Gig. Sanit. 2017; 96 (2): 166-170.

19. Al-Kaabba A.F., Saeed A.A., Abdalla A.M., Hassan H.A., Mustafa A.A. Prevalence and associated factors of cigarette smoking among medical students at King Fahad Medical City in Riyadh of Saudi Arabia. J. Family Community Med. 2011; 18 (1): 8-12.

20. Melaku L., Mossie A., Negash A. Stress among Medical Students and Its Association with Substance Use and Academic Performance. J. Biomed. Educ. 2015; 2015: Art. 149509. URL: https://www.hindawi.com/journals/jbe/2015/149509/.

21. Silva V., Costa P., Pereira I., Faria R., Salgueira A.P., Costa M.J., Sousa N., Cerqueira J.J., Morgado P. Depression in medical students: insights from a longitudinal study. BMC Med. Educ. 2017; 17 (1): 184

22. Egnew T.R., Lewis P.R., Schaad D.C., Karuppiah S., Mitchell S Medical student perceptions of medical school education about suffering: a multicenter pilot study. Fam. Med. 2014; 46 (1): 39 44.

23. Chen L., Zhao R.L., Chen H. Association between coping styles and non-suicidal self-injury among undergraduate students in Wuhan. Zhonghua Liu Xing Bing Xue Za Zhi. 2017; 38 (12): 1607-1610.

24. Dunn L.B., Iglewicz A., Moutier C. A conceptual model of medical student well-being: promoting resilience and preventing burnout. Acad. Psychiatry. 2008; 32 (1): 44-53.

25. Chang E., Eddins-Folensbee F., Coverdale J. Survey of the prevalence of burnout, stress, depression, and the use of supports by medical students at one school. Acad. Psychiatry. 2012; 36 (3): 177-182.

26. Egnew T.R., Lewis P.R., Meyers K.R., Phillips W.R. The suffering medical students attribute to their undergraduate medical education. Fam. Med. 2018; 50 (4): 296-299.

27. Shcherbatykh Yu.V. Psychology of stress [Psychology of stress]. M.: Eksmo, 2006. 304 p. (In Russ)

28. Spitzer R.L., Kroenke K., Williams J.B.W., Lowe B. A brief measure for assessing generalized anxiety disorder. Arch. Intern. Med. 2006; 166 (10): 1092-1097.

29. Lovibond P.F, Lovibond S.H. The structure of negative emotiona states: comparison of the Depression Anxiety Stress Scales (DASS) with the beck depression and anxiety inventories. Behav. Res. Ther. 1995; 33: 335-342.

30. Vasil eva L.N., Shchepetkova S.S. About suicidal risks of medical students [About suicidal risk in medical students]. Historical and social educational ideas [Historical and socio-educational thought]. 2015; 7 (3). 179-183. (In Russ)

31. Nasrallah, H. A., Smeltzer D. J. Contemporary diagnosis and management of the patient with schizophrenia. Newtown, Pa: Handbooks in Health Care Co., 2002. 248 p. 
32. Яковлева А.Л., Симуткин Г.Г. Влияние коморбидности аффективных и личностных расстройств на основные клинические характеристики текущего депрессивного эпизода и суицидальное поведение. Суицицология. 2014; 5 (3): 47-52.

33. Labouliere C.D., Kleinman M., Gould S. When self-reliance is not safe: associations between reduced help-seeking and subsequent mental health symptoms in suicidal adolescents. Int. J. Environ. Res. Public. Health. 2015: 12 (4): 3741-3755.

34. Bazmi Inam S.N. Anxiety and Depression among Students of a Medical College in Saudi Arabia. International Journal of Health Sciences, Qassim University. 2007; 1 (2): 295-300.

35. Jadoon N.A., Yaqoob R., Raza A., Shehzad M.A., Choudhry Z.S Anxiety and depression among medical students: A crosssectional study. J. Pak. Med. Assoc. 2010; 60: 699-702.

36. Qamar K., Khan N.S., Bashir Kiani M.R. Factors associated with stress among medical students. J. Pak. Med. Assoc. 2015; 65 (7): 753-755.
32. Yakovleva AL, Simutkin G.G. The influence of comorbidity of affective and personality disorders on the main clinical characteristics of the current depressive episode and suicidal behavior. $\mathrm{Su}$ icidology. 2014; 5 (3): 47-52. (In Russ)

33. Labouliere C.D., Kleinman M., Gould S. When self-reliance is not safe: associations between reduced help-seeking and subsequent mental health symptoms in suicidal adolescents. Int. J. Environ. Res. Public. Health. 2015: 12 (4): 3741-3755.

34. Bazmi Inam S.N. Anxiety and Depression among Students of a Medical College in Saudi Arabia. International Journal of Health Sciences, Qassim University. 2007; 1 (2): 295-300.

35. Jadoon N.A., Yaqoob R., Raza A., Shehzad M.A., Choudhry Z.S.. Anxiety and depression among medical students: A crosssectional study. J. Pak. Med. Assoc. 2010; 60: 699-702.

36. Qamar K., Khan N.S., Bashir Kiani M.R. Factors associated with stress among medical students. J. Pak. Med. Assoc. 2015; 65 (7): $753-755$

\title{
SUICIDAL BEHAVIOR IN THE STRUCTURE OF PROTECTIVE METHODS OF OVERCOMING MIGRATION AND EDUCATIONAL STRESS BY FOREIGN STUDENTS
}

\author{
V.V. Ruzhenkova \\ Belgorod National Research University, Belgorod, Russia; ruzhenkova@bsu.edu.ru
}

\begin{abstract}
:
Medical students who come to study in another country experience certain difficulties in adapting to the norms and values of the host culture, as well as significant academic stress, accompanied by anxiety and depression. This study aimed to develop recommendations for overcoming the educational stress by medical students who came from other countries on the basis of studying its prevalence, phenomenological manifestations and determining factors. Material and methods. A solid sample consisting of 166 students from 1 to 3 courses was examined using the medicosociological and psychometric methods. All students arrived from the countries of the Middle East and India, do not speak Russian and was trained in the intermediate language (English) at the medical institute. Nonparametric statistical methods were used to process the results. Results. It is found that foreign students in the first months of adaptation experienced stress, which was accompanied by internal forms of suicidal behavior in $44 \%$ of cases. At the same time, the severity of suicidal thoughts on a 10 point scale was 5-9 points in $29.7 \%$ of first-year students, $27.3 \%$ in sophomores and $14 \%$ in third-year students. The main symptoms of stress are the influx of extraneous thoughts, depression, irritability, anxiety, as well as vegetative symptoms (rapid heartbeat, shortness of breath, headaches, and problems with the gastrointestinal tract) that are part of the depressive and anxiety-depressive syndromes which are the psychopathological basis for the occurrence of suicidal behavior. It should be noted that suicidal thoughts were more frequent among students experiencing medium and serious difficulties during their studies ( $U=630.0 ; Z=-2.16$; $\mathrm{p}=0.031)$. The probability of depression in first-year students is 2.6 times higher $(\mathrm{OR}=2.6 ; 95 \%$; $\mathrm{CI}=1.2-5.7)$ than in the second and is found in $31 \%$ and $17.8 \%$ of students, respectively $\left(\chi^{2}=6.3 ; \mathrm{df}=1 ; \mathrm{p}=0.013\right)$. Anxiety of varying severity was observed in $50 \%$ of 1 st-year students and $35 \%$ of the second and third. To overcome the stress, students use infusions of herbs and non-prescription sedative drugs. At the same time, students who had suicidal thoughts in the period of adaptation, more often than students without suicidal thoughts, took infusions of herbs $(\mathrm{p}=0.002)$ and nonprescription sedatives $(\mathrm{p}=0.016)$ to overcome the stress. From 1 to 3 courses there is an increase in the number of foreign students who use alcohol and who resort to tobacco smoking. The conclusion. This requires training students in constructive ways to overcome stress, proper time planning, methods of optimal work with educational literature, which will help to overcome migration and educational stress, and will improve adaptive opportunities.
\end{abstract}

Keywords: educational stress, migration stress, medical students, suicidal behavior, autoaggressive behavior

Финансирование: Исследование не имело финансовой поддержки.

Конфмикт интересов: Авторы заявляют об отсутствии конфмикта интересов.

Для цитирования: Руженкова В.В. Суицидальное поведение в структуре защитных способов преодоления миграционного и учебного стресса иностранными студентами. Суицидология. 2018; 9 (4): 47-60. doi.org/10.32878/suiciderus.18-09-04(33)-46-60

For citation: $\quad$ Ruzhenkova V.V. Suicidal behavior in the structure of protective methods of overcoming migration and educational stress by foreign students. Suicidology. 2018; 9 (4): 47-60. (In Russ) doi.org/10.32878/suiciderus.18-09-04(33)-47-60 